\title{
T-shirt or folk costume - choice of clothing by context
}

\section{Clothing and the language of clothing}

Roland Barthes suggests that clothing indicates the social status, sex, identity and values of the wearer. This structuralist approach treats clothing as a language system and a way of communication. The language or clothing system presumes two components: the sender of the message or wearer of the clothing and the receiver of the message or interpreter. The system of relationship between the two sides makes up the 'vestimentary code', an analogue of the language system. The sign results from the union between the sender of the message and the receiver (Barthes 1967: 217). Fashion clothing is used here to indicate costume as an interpreter of identity. This kind of view suggests that the identity of the wearer has been compared with a game. Fashion clothing exists without signifying, it is a sign of two identities: of one's own identity (what a man believes he is and defines as real about himself), and of an 'other' identity (which the wearer hopes to identify with, and one that the others believe he has). The wearer of fashion clothing could be 'self' and 'other'. ("On voit donc la femme de mode rêver à la fois d'être soi et d'être une autre." Barthes 1967: 259.) The idea that fashion clothing is a game raises a question about the meaning of clothing: is clothing a game or does it have the meaning of a game? Barthes points out that the fashion system is a play on identities. In this play, the aspect of identity is not so serious and is not characterized by answers to such questions as "Who am I?" or "Who are you?" (Barthes 1967: 259). He compares fashion clothing to a keyboard which the woman uses to choose the theme for the day, a sort of luxury whereby she can change her dress and at the same time change her identity.

The wearer of fashion clothing has to answer the questions "Who am I?", "Where?" and "When?" The question relates to personal identity and suggests clothing as the answer. (Barthes 1967: 252.) Questions about space and time include activity on the part of the user/wearer: to reach the desired identity the wearer has to change her clothes. Fashion clothing signifies social distinctions of age, gender and status. The vestimentary code includes clothing for work, sport and hobbies. The practical side of life, everyday life, is marginal, and most of the meaning or significance relates to festive occasions. (Barthes 1967: 254.)

Fashion and the terminology of fashion form a vestimentary code which is known to the members of society. What about folk costume? What is 'folk cos- 
tume' nowadays? In modern societies it is a series of variations of dress, and post-modernity means multiple styles and opportunities for choosing our dress. One's clothes are a visible indication of one's personal and social life. Tim Dant studied clothing relating to modernity. He describes blue jeans as a 'classic' form of clothing (Fiske 1989: 1-21; Dant 1999: 102) and suggests that "Denim jeans threatened to break with the tranquil order of modern life when they moved from rural work clothes to become an emblem of urban youth reacting activity. ... Jeans went against the grain of the dominant clothes culture of western modernity and reversed many established clothing signifiers." (Dant 1999: 103.) Jeans are characterized by many meanings, and it is difficult to adapt the connotation theory of Roland Barthes. The shape of jeans does not suggest any connotations of class, sex or even nationality. (Dant 1999: 107.) Jeans made of cotton, flannel or twill, jeans decorated with embroidery and buttons. The cutting of the body by the seams of the jeans presents the sexual parts. In a global world, blue jeans represent a piece of cloth, well-known and used everywhere without any limitations. Jeans are clothing for urban youth and for adults, and are worn by both sexes.

By wearing clothes, the wearer sends messages, but what are the connections between the wearer and the receiver? Here, I endeavour to study clothing as a system, as Barthes suggests, and ask the question: how do the members of society understand the messages? If the sender of the message knows the vestimentary code, does the receiver interpret the message that is intended for the unconscious?

\section{Clothing as experience}

\section{Young girls in the village of Shorunzha'}

I observed the clothing in the village of Shorunzha in the Mari Republic in Russia over a period of three years. I wanted answers to such questions as "What is the clothing system in this village?", "How do the inhabitants understand the message of this system?" and "How can the 'others' understand this message?"

In this paper, I want to focus my attention on the clothing of girls aged 914 . Why observe only the clothing of teenage girls? Over four summers I interviewed Mari women of different ages. When I talked to the grandmothers, the grandchildren bustled about under our feet. When I was with mothers aged 30

\footnotetext{
${ }^{1}$ The name of the village in the Mari language is Uncho. I should like to thank Gennadiy Grigor'yev, president of the cooperative, and Ivan Yevsev'yev, director of administration, for their help during my fieldwork in 2001 to 2004. I am very grateful to all the women, girls and other inhabitants of Shorunzha for their positive attitude.
} 
40, their daughters often participated in the interview smiling quietly. The teenage girls were in the background as a visible and silent witness. The girls and their clothing only attracted my attention in August 2003. The artist, Tiiti Mendelin, was working with us in the field, drawing and painting all time. Like my camera, the artist's drawing was a magnet for the girls. When we walked down the street, we immediately had company. There were teenage girls and boys who followed curiously the steps of the 'foreigners'. My camera and the drawing paper were a magic wand, and when they appeared the girls appeared at the same moment, giggling or silent. Gradually, they became models for our artist. In May 2004, the situation changed completely. The young girls asked to pose for the camera or for the artist more and more often. It was a demand, made with smiling or silent expectant features. At this point, my attention was attracted to the teenage girls' clothing and their way of life in the village.

The teenage girls are a visible part of the everyday life of the village. I saw girls going to school, shopping, going to fetch water, washing by the well, running errands for the family, playing in the street, walking, etc. The school is part of the public space; the girls comport themselves as if in the street wearing different clothes according to the context. The girls follow their grandmothers and mothers to the places where feasts are held. They visibly participate in festivals and village feasts. The girls visit the sacred places, too.

What were the girls wearing? I made my observations in the field in spring and summer; in June 2002, August 2003 and May 2004. I saw T-shirts, sleeveless tops, sweatshirts, sweaters, dresses, folk costumes, jeans, cycling shorts, richly coloured tights, windcheaters, tracksuits and blazers. Various caps, gym shoes, pumps, plimsolls, galoshes and rubber boots finished of the outfit depending on the weather. The same clothes were sold in the village market every Monday, in the market in the nearby village of Morki, and in the 'city', which meant the city of Yoshkar-Ola, the capital of the Mari Republic, or the city of Kazan, the capital of Tatarstan.

What is their clothing system? What are the different models of wearing? How does the system of clothing work? And finally, I would like a response to the question "What does the vestimentary code mean, does it have a conscious or an unconscious meaning?"

\section{In the street}

At the well. Marina and Valia are doing the washing. Valia is dressed in fine stone-washed jeans, a violet velour blouse and galoshes, and has earrings in her ears. Marina is dressed in 'workwear' consisting of blue trousers and a blue sweatshirt. Tania came to fetch water. She has a blue yoke or cowlstaff with blue buckets, which are smaller than her mother's. Tania is dressed in jeans, T-shirt and sweater. (2004) 
The main street of the village is a public space; the teenage girls have to run anywhere and everywhere, but they are always dressed well. The difference between ordinary days and feast days is not reflected in the clothing; the girls go to fetch water wearing brand-new sleeveless tops, new sequinned jeans and earrings in their ears. These clothes represent their desire for fashion, their parents' tolerance and their financial situation.

What combinations of clothes are there in the street and at home?

1. Jeans and a coloured T-shirt was the most common form of dress. The girls wore sweaters, too, in the morning and evening. Covering the head was very popular; girls of 4-9 wore scarves, the teenagers wore caps.

2. Shorts and top was the alternative dress in the heat of midday. The tops were short, to the waist, with thin straps.

3. Tracksuits, blouses and sweatshirts were used in cold weather. The girls did their housework dressed in trousers and sweatshirts; May was very cold in 2004.

4. Cotton dresses were going out of use and being replaced by trousers of different types. In June 2002, I observed many girls playing in the street wearing dresses with small collars or flounces. In May 2004, I saw only a few girls of school age in dresses, which had become a sign for smaller girls of $4-8$.

The meaning of the fashion clothes is clear from the wearer's point of view. T-shirts and sweatshirts are practical items of clothing and at the same time much in demand. Practically all shirts are decorated with text or pictures. There was lettering from different brands and pictures representing figures from soap operas or cartoons. In August 2003, Harry Potter and Pokemon were both very popular patterns. The letters were usually written in English, and the wearer often did not realise their content. When I asked the girls what the text meant, they responded "I don't know, but it isn't important." The majority of shirts and sweatshirts were bought in the market, and represented cheap imports from Korea, China or Turkey. For example, I saw a few T-shirts bearing the text I lov You.

The shirts and sweatshirts were 'in' by virtue of their novelty. What does it mean? What are the essential features of the phenomenon? Does the wearing of a T-shirt indicate the context? Are the T-shirt and the sweatshirt clothing that has meaning?

The most important feature of these shirts is that they are newly bought. For example, the village market was held on Monday, and Tania's mother bought her a flowered T-shirt. She wore the new T-shirt to school, then at home and in the evening after the sauna. The others girls followed the same pattern, although it was a normal day. The new shirt included a message about the fi- 
nancial status of the family: the family is able to provide the child with something new. The T-shirt or sweatshirt has a meaning, and an important one, from the viewpoint of teenage girls. It is a sign of the identity of the teenage girl, a clear message that she belongs to a group of young people who know about the fashion of the day. They follow fashion; they dress like young girls anywhere in Europe or elsewhere. The T-shirt and sweatshirt form a bridge or link with young people across the world. They are trying to find the way the modern world is going. What does the modern world mean for the girls? It is urban life, a different and easier life than the hard country life their mothers and grandmothers knew. For the teenage girls, wearing the latest trends is a sign of identity. This message is a very strong and consciousness one.

The economic and sociological situation is fairly heterogeneous in the village. However, I observed a fine and scarcely visible dichotomy between the different groups. It was a children's day in June 2004, and the girls were clearly divided into two groups. One group wore folk costume and the other dressed in fashion clothes. I do not think the young people have their own subculture in the village of Shorunzha, but there is an intention to differ from 'the rest' and form a 'separate' group. For teenage girls, fashion clothes are a clear message of identity.

According to Stuart Hall, modern societies are by definition in a state of constant, rapid and permanent change (Hall 1992: 277). The village of Shorunzha is part of modern society, and the young people act like young people anywhere in the world. However, the economy of the village follows the traditional pattern, but the way of life has definitely changed. The young girls watch soap operas and reruns on TV, they read women's and young people's magazines and hear about the experiences of family members in the city. They know about urban life, and they know about the meaning of the world. Stuart Hall (1992: 280 ) suggests that "identity shifts according to how the subject is addressed or represented, identification is not automatic, but can be won or lost." In my opinion, the fashion clothing of teenage girls is a sign of their identity as young people. This identity is strong, but the emergence of this identity is a process that has only recently begun.

What is the message of this new trend for the other villagers? That is, for the mothers or grandmothers who buy the fashion clothing. I noticed that they like the colourful T-shirts and sweatshirts very much. These clothes, decorated with pictures or sequins were 'very beautiful' (Mari pesh motor) in their opinion. The mothers and grandmothers understand the motives of the user/wearers: the girls are trying to follow the new trend and at the same time identifying with the group of girls aged 14-18.

The grandmothers' generation is well disposed towards the girls' colourful clothing. They grew up in the period of socialism, after the Second World War, when folk costume, with the embroidered white shirt, was the only clothing. 
During the 1950s, the assortment of clothes in stores was limited and prices were too high for most people. Soviet textile production did not give the Russians or the Mari the opportunity to choose fashionable clothing. (Vainshtein 1996: 65.) During that period, the Soviet woman's wardrobe included a khalat for housework. For Mari women the khalat was a dream, and they have only been able to buy a khalat made of flowered cotton since the 1960s. The khalat is fairly popular with everyone. Elderly women wear the khalat in the street and at home. The young women and girls only wear the khalat in the morning and after the sauna. The colour of the khalat was similar to that of the shirt, and the elderly women accept it without comment. They agree with the girls and buy the ever-popular T-shirt or sweatshirt, if they can afford to.

What about jeans? What do the villagers think about jeans? For the young people, jeans mean trendiness, fashion and internationality. They say, "How can we dress without jeans?" For them, jeans are an essential part of their clothing, they are self-evident, "Everyone wears jeans." Young girls sneer at their mother's or grandmother's clothing as they do not wear jeans; they hear stories of 'the good old days' and look at old photographs critically. From the girls' point of view, jeans are a sign of trends, of being 'cool' and of modern life. Their jeans represent the last phase of low-cost production. The legs of their jeans are decorated with embroidery, sequins or beads and sometimes with studs. The girls' mothers buy jeans in the market, because 'everyone' wears them, and the identity of the group is growing stronger and stronger.

What do the grandmothers think about jeans? For me that was a very interesting question, and I noticed that jeans did not invoke negative feelings. Firstly, the girls' jeans were almost always decorated, and the decoration phenomenon responded to the aesthetic tastes of elderly people. The second reason is that white cotton pants were part of the Mari women's folk costume. The third reason is that trousers became clothing for girls throughout the school. Since the 1960s, Mari families have been buying tracksuits for boys and girls, which became practical items of clothing for them.

How can we define the meaning of jeans from a gender viewpoint? In the last few years, jeans have been included in the clothing of both sexes. Adults do not see any negative features in jeans, they are getting used to them through the medium of television. Jeans are used by both sexes, but decorated jeans are only a 'girls' thing'. Traditionally, Mari women like colourful and richly decorated dress. Embroidery, sequins, beads and studs are popular and 'very nice' especially for women. "Girls look good in jeans," said one of the mothers.

What is special about the jeans, T-shirt and sweatshirt phenomenon in this Mari village? Can it be compared with the Finnish teenage girl's look? In the last few years, Finnish girls of 13-14 have begun dressing like older girls in richly decorated jeans and short, tight tops. In Finland, the term pissis (English 'would pee') is used as a derogatory term for teenage girl favouring Miss Sixty 
jeans (http://en.wikipedia.org/wiki/Pissis). The girls emphasise their nascent femininity by wearing the clothing of disco-singers or soap operas. Their mothers follow this phenomenon with understanding and allow the girls to buy sleeveless tops and decorated jeans.

In the village of Shorunzha, the young girls form a link between the village and the world. The vestimentary code sends a message looking towards the future in two ways. The future is another place, perhaps an urban one, and the future is a woman's life based on sexuality.

\section{In the school}

It was the last day at school, and we had a celebration. The young girls were wearing black dresses and white aprons, looking very funny, with their tights glistening and their white bow-ties swaying in the wind. Most of the schoolgirls dressed any which way, the future first class and those in the ninth and tenth classes in party clothes. The tenth class wore black dresses and white aprons, the first and the ninth class wore white blouses and black skirts. It was very cold. We heard speech after speech, watched the dancing and, finally, we followed the dialogue between the future first class and the tenth class. The programme lasted a long time, we were freezing and the children looked shivery. The speaker was a 16-year-old girl dressed like a dream in a pink princess dress, light as a breath of wind, short and sleeveless, with garlands in her hair. (June 2004)

In the school I noticed three models of behaviour:

1. The girls dressed in the same fashion clothing as in the street, and also looked very nice.

2. At the end of summer, the girls wore party clothes, consisting of black dress with white apron or white blouse with black skirt. The school uniform carries the message of school rules, i.e. accept and follow the norm. But these clothes are not obligatory, and the white blouses make it possible to differ from the rest of the group. In the past, the uniform was a sign of social status, since all pupils went to the same state schools.

3. The uniform of the Soviet era is still in use, but the meaning has changed. It is the party dress of the tenth class, the sign of the end of school time.

The black-and-white clothes are a relic of the Soviet era. Sheila Fitzpatrick and Raymond Hutchings take the view that "uniforms were associated with order and propriety and the inculcation of responsibility and pride of the collective." (Fitzpatrick 1999: 107; Hutchings 1976: 190.) The uniform diminished social distinctions within the school. Since 1992, the uniform became facultative. The 
black-and-white outfit has a secondary function like a sign. The white blouse gives the girls a chance to show off new trends. The uniform did not respond to the code; the message became fuzzy from the point of view of the wearer and of the observer, too.

The girls did not accept the original message of uniform relating to order and solidarity. The black dress is very short and fitted, and the white apron accentuates their womanly figures. If anything, the dress exposes more than it covers. The dress became a joke during the socialist period. The girls know that the message of uniform is a different one. At the moment, the uniform is a sign of identity for schoolgirls, but only sometimes, at certain moments. The wearers of uniform become conscious of that new message, but the observers do not really understand that. The mothers often appreciate the new meaning of uniform; they often pass on their own dresses for the occasion. But the grandmothers do not understand the new message. They remember their own schooldays, the rules and the order. For them the uniform cannot include jokes of any kind. The grandmothers wonder why their grandchildren are dressed in that way, only on the last day of school. For them, the vestimentary code of the uniform is not clear.

\section{Folk costume}

Children's day. The small girls and boys sing and dance on the stage; they dance very well in the Mari way. The teachers guide the celebrations. The little girls wear dresses with collars, the boys wear white shirts, black trousers and jackets. The girls of 9-14 are wearing folk costume or national dress. (June 2004)

I saw Mari folk costume at different celebrations, national festivals and sacred feasts. The folk costume is an integral part of Mari song and Mari dances; it is a national dress, a sort of representation of Mari identity. Within the family, the grandmother is often responsible for the folk costume, she makes it herself or she buys it for her granddaughter. It depends on the grandmother, how often the girl wears her folk costume. The old woman takes the girl with her on different occasions and teaches her how the folk costume should be used.

In a way, the use of folk costume was problematic. I tried to understand why anyone should dress in folk costume today. T-shirt and jeans are part of everyday life and feast days, while school uniform is part of the end of school time, but what is the meaning of folk costume. I noticed that every girl has some kind of folk costume. What does it mean? Is it a sign of Mari identity? And if so, what is the meaning from the point of view of the wearer and the observer? I observed two different folk costumes: 
1. The folk dress of Yoshkar-Ola includes a white shirt and apron. Both items of clothing are decorated with flowered embroidery and lace. The pattern of the long shirt is simply straight. Almost every woman knows how to make folk costume, and the girls often sew it themselves. Sometimes the grandmother will begin the dress and the granddaughter will finish it. The embroidery is the most important feature; the hem and the front are largely embroidered with coloured flowers in satin stitch.

2. There has been a dressmaker's shop in the village since 1989. The workers make folk costumes to order for folklore ensembles and individuals. The pattern and the colour of the dresses follows the traditional costume. The embroidery is very complicated, including running and satin stitch, 'Holbein stitch'. The patterns are geometric and very old. The embroiderers design the patterns themselves using books and traditional clothing. I think this type of national dress could be defined as a 'neo folk costume'. It takes a long time to make a neo folk costume, and it is very expensive. The dressmakers also wear these dresses, and I noticed some neo folk costumes at the national festival. Neo folk costume is very popular and 'in', and from the girls' point of view it is more interesting than their own embroidered folk costume.

The Mari folk costume is self-evident; all girls know how folk costume should look. For the majority of girls, the costume is very beautiful and responds to their aesthetic taste. The girls known that the folk costume is a sign of Mari identity. Almost every girl answered, "I have a Mari folk costume, because I am a Mari." The folk costume is connected with the other signs of Mari identity, Mari songs and dances. The girls dance Mari dances wearing the folk costume in the Mari way. It is national dress, and the meaning is clear for all the villagers. Mari women like the richly coloured and embroidered costume. The most popular soap opera in the village was a Brasilian one, because of its decorated clothing.

There was a national festival in June, and the girls dressed in national costume were walking in the village, in the streets and the parks. From the point of view of foreigners, of 'others', the national dress looked like a part of everyday life in the village. After the festival, the national dress is put away in the cupboard. The national dress answers the question "Who am I?" That code is visible in the village only at festival time.

The girls wear the folk costume, because it is aesthetically very attractive. At the same time, the costume is a responsibility; the girls have to participate in the singing and dancing at the festival. For the girls, the national dress is a clear sign of Mari identity. That is another reason to wear national dress. The foreigners, the others, take an interest in Mari dress, which influences the girls' opinion. 


\section{Conclusions}

The Mari folk costume has been studied at length. The Mari ethnographer, Tamara Molotova, has creditably surveyed the different variations of local folk costume based on field work since the 1970s. (Molotova 1989; 1992; 2002.) I have tried to study the activities of Mari women in making clothing for themselves and their families and in using the clothing, and approached the problem of the transformation of clothing over the last 20 years (Lehtinen 1994; 1999; 2000). It is true that of all things, clothes are the material objects that are most consistently part of our individual and our social lives. (Dant 1999: 85.) Folk costume is the most visible indicator of identity. The Mari folk costume remained in many of the villages until the 1960s. It was the symbol of identity for the Mari people and at the same time the sign of the local group. In the postsocialist period, the national identity exists in relation to other cultures and other worlds. National identity is a theoretical truth. The vestimentary code demands a written or an oral system. In the Mari village, clothing is a material experience. The villagers can choose different ways of clothing; there are no limits to the series of items of clothing. Each individual chooses her clothes according to her own requirements and to suit the context.

What about the clothing of teenage girls? In my opinion, the Mari girls have three models of behaviour, and in consequence three different clothing combinations reflecting contexts and identities. Their everyday clothing and party clothes are a sign of the young people's group, they form a link with the rest of the world and reflect the girls' hope for another way of life. This clothing is a bridge to the future, when the girls will be living in another place. For the present, the uniform is the sign of the school, but this message is not clear; the girls use the uniform at the end of the school, for a few days. The Mari folk costume reflects the Mari national identity, which is actualised only on feast days, at Easter, Pentecost, and at national festivals and sacred feasts.

The clothing of teenage girls is a part of their worldview. Fashion clothes are a sign of the other world, of the possibility of getting away from the village and the bustle of everyday life, from work morning, noon and night. It indicates a wish to move to the city, to the other world. This phenomenon is global and similar for all young people; it relates to young people's identity. The folk costume tells the other side of the story; the girls like the country life; they talk about the wonders of nature, the fresh air, the cleanness and the people.

In post-modernism, identity is always in a state of flux and always being formed. (Hall 1992: 287.) The Mari village of Shorunzha is inhabited by Mari people, but the village is in the Mari Republic, which is composed of several nations and several cultures. The vestimentary code is in a state of change, too. 


\section{Picture captions}

Picture 1. Tania at the well.

Picture 2. Sacrificial feast in May.

Picture 3. The speaker and the tenth class.

Picture 4. Children's day festival.

Picture 5. Last day at school.

All photos: Ildikó Lehtinen 2004. National Board of Antiquities.

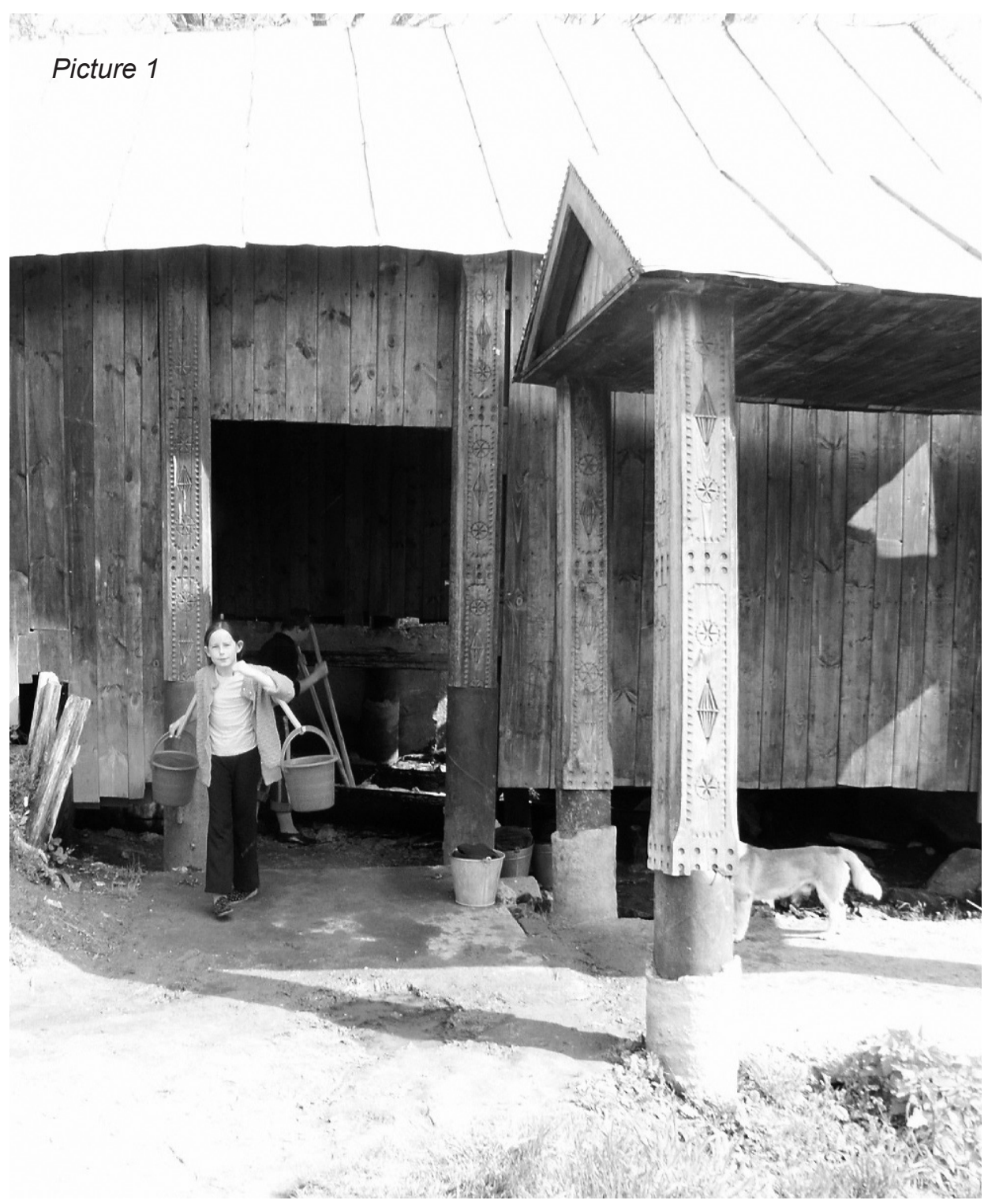




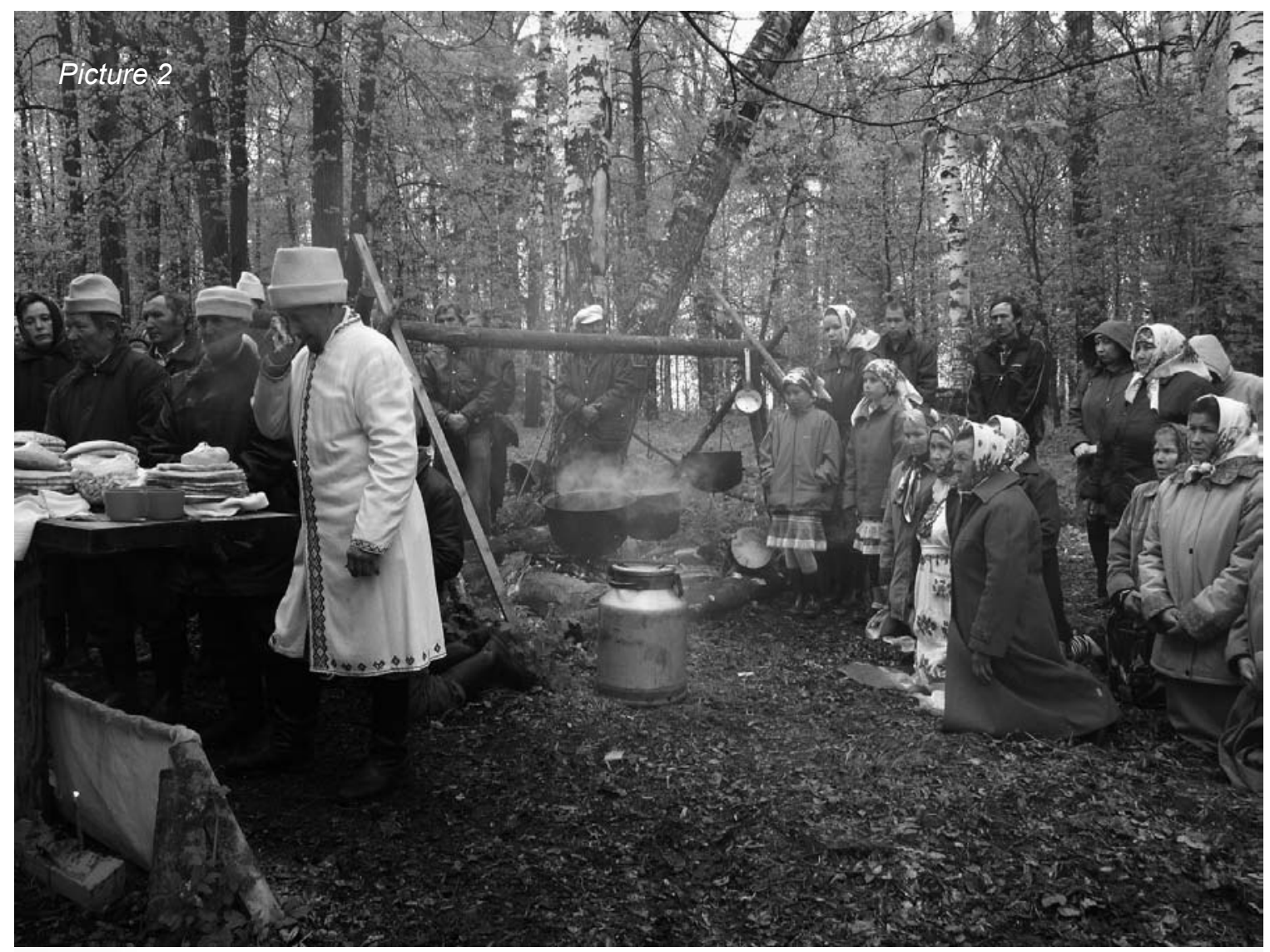

Picture 3

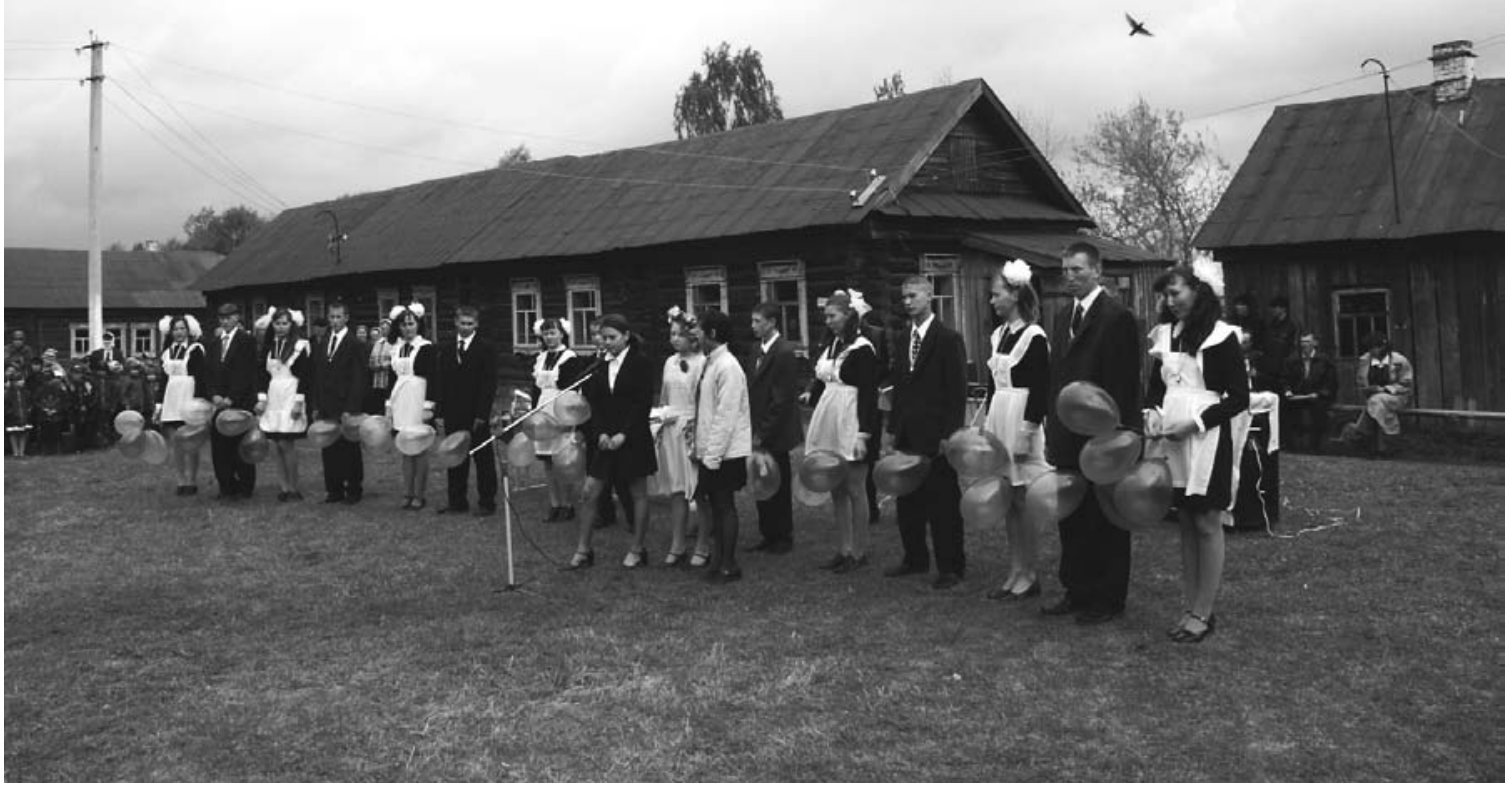


Picture 4

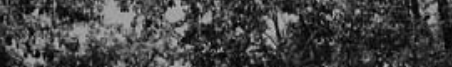

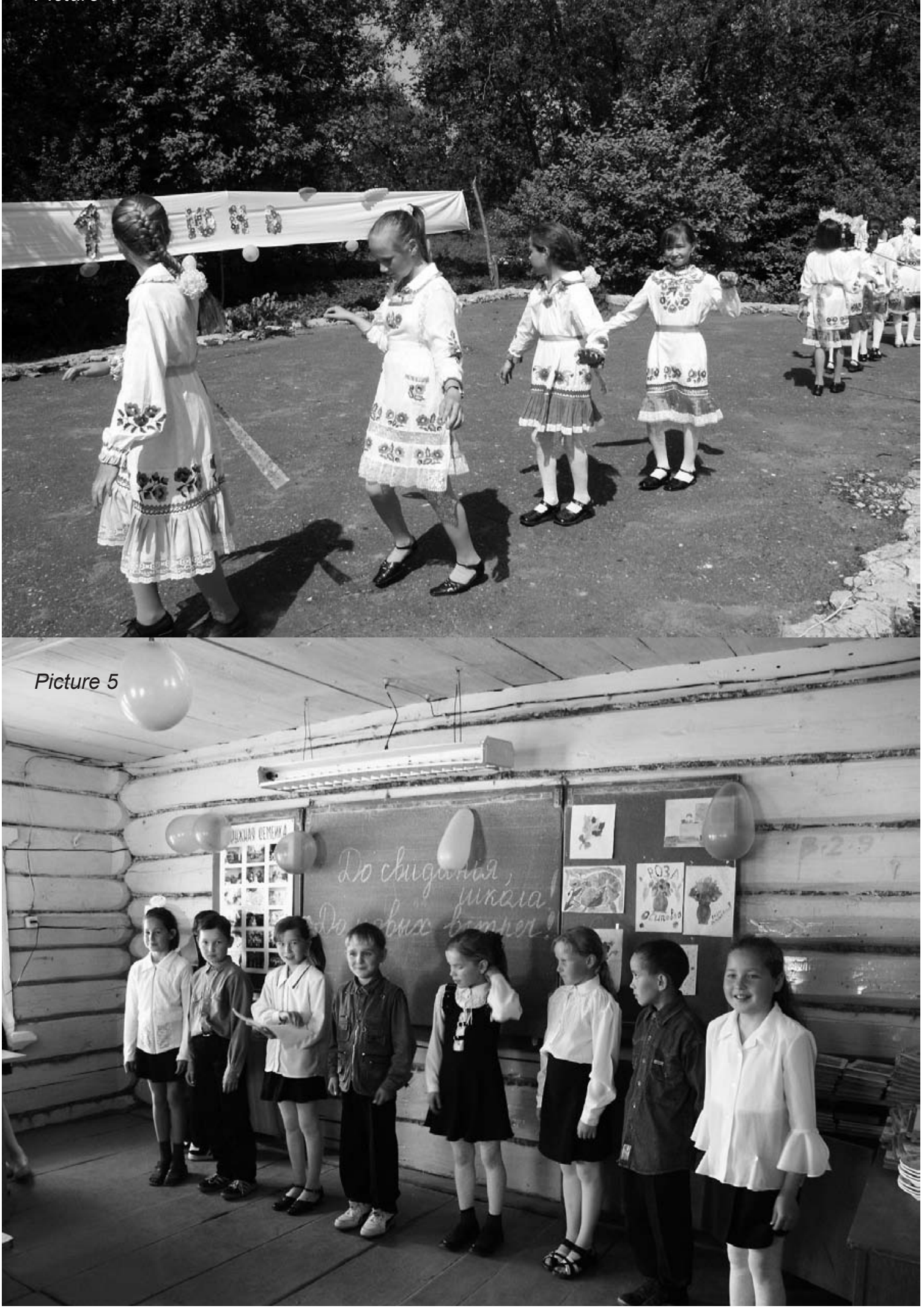




\section{References}

\section{Unpublished sources}

Lehtinen, Ildikó: Field notes in the village of Shorunzha 2001-2004. Archives of the Museum of Cultures / National Board of Antiquities.

\section{Published sources}

Barthes, Roland 1967: Système de la mode. Seuil.

Dant, Tim 1999: The material culture in the social world. Values, activities, lifestyles. Buckingham - California.

Fitzpatrick, Sheila 1999: Everyday stalinism. Ordinary life in extraordinary times: Soviet Russia in the 1930s. New York - Oxford.

Hall, Stuart 1992: The question of cultural identity. - Stuart Hall, David Held \& Tony McGrew (eds.), Modernity and its futures. Cambridge.

Hutchings, Raymond 1976: Soviet science, technology, design. Interaction and convergence. London - New York - Toronto.

Lehtinen, Ildikó 1994: Tscheremissischer Schmuck. Ethnographische Untersuchung. Travaux ethnographiques de la Société Finno-Ougrienne 14. Helsinki.

Lehtinen, Ildikó 1999: Marien mekot. Volgansuomalaisten pukujen muutoksista. Travaux ethnographiques de la Société Finno-Ougrienne 16. Helsinki.

Lehtinen, Ildikó 2000: Chest and cupboard: A case of identity in a Mari village. Ethnologia Fennica 28/2000. Helsinki.

Molotova = Молотова, Т. Л. 1989: Локальные комплексы традиционного марийского женского костюма. - Археология и этнография Марийского края 16. Йошкар-Ола.

Molotova = Молотова, Т. Л. 1992: Марийский народный костюм. Йошкар-Ола.

Molotova = Молотова, Т. Л. 2002: Традиция и инновация в народном костюме марийцев. - Н. Ф. Мокшин (ed.), Современная этническая культура финноугров Поволжсья и Приуралья. Йошкар-Ола.

Vainshtein, Ol'ga 1996: Female Fashion, Soviet Style: Bodies of Ideology. - Helena Goscilo \& Beth Holmgren (eds.), Russia \& women \& culture. Bloomington Indianapolis.

Ildikó Lehtinen <ildiko.lehtinen@nba.fi>

National Board of Antiquities

P.O. Box 913

FI-00101 Helsinki 